\title{
NEW BABY WELCOMING CELEBRATION IN SALUAN AND KOREA
}

\author{
Hardianti ${ }^{1}$, Sulistiyani ${ }^{2}$ \\ ${ }^{1}$ PBI FKIP UM Luwuk, ${ }^{2}$ PBI STKIP Bina Ihsan Mandiri Surabaya \\ Email: hardianti@unismuhluwuk.ac.id ${ }^{1}$, sulistiyani@ stkipbim.ac.id ${ }^{2}$
}

\begin{abstract}
Abstrak
Setiap budaya memiliki cara mereka dalam menyambut kehadiran anggota baru dalam keluarga mereka. Penelitian ini memberikan informasi terkait perayaan penyambutan bayi dalam dua budaya yang berbeda: Saluan dan Korea. Penelitian kualitatif ini menemukan beberapa perbedaan dalam perayaan di kedua budaya tersebut, juga nilai-nilai di dalamnya. Perbedaan-perbedaan yang ditemukan berkaitan dengan waktu dan jumlah rangkaian acara yang ada dalam perayaan. Dengan meningkatnya pemahaman kedua budaya, apresiasi dan kecintaan terhadap budaya local juga bisa meningkat.

Kata kunci: Perayaan Menyambut Bayi; Saluan; Korea.
\end{abstract}

\section{Abstract}

Every culture has its way to celebrate the appearance of a new family member. This study provides some information related to the new baby welcoming celebration of two different cultures: Saluan and Korea. This qualitative study finds some similarities within the celebration as well as their values behind. The differences found in the case of time and the number of events included in the celebration. Hopefully, with the rise of understanding of the two cultures, the appreciation and affection towards local cultures can also be improved.

Keywords: New Baby Welcoming Celebration; Saluan; Korea. 


\section{Introduction}

Bringing a new baby home is one of the most exciting universal human experiences. For most parents, it is a time of celebration when families and communities come together to honor and welcome the new child (ParentMap, 2005). In every place in the world, people have their way to celebrate the arrival of a baby.

Indonesia which is well-known for its multicultural society has various ways of celebrating the arrival of babies. From Sabang to Merauke, Miangas to Rote Island, each of the tribes in Indonesia has their typical celebration, no exception for people of the Saluan tribe.

Saluan is one of the main tribes in the Banggai Regency, located in the east of Central Sulawesi province in Indonesia, besides Banggai and Balantak. Many of Saluanesse people spread in the southern, western, and some of the eastern sides of Luwuk, the capital city of Banggai Regency. Saluan is the largest tribe inhabiting in Banggai District (Mangundap, Waani, Tungka, 2017).

The Saluan tribe is divided into two largest religions: Christian and Islam. The late is mostly embraced by those who live in the south of the Banggai Regency. It is reflected in some parts of a celebration ceremony of a baby welcoming event in a Saluanesse-Muslim family like the reading of certain praise to God, the Alaho (literary refers to Allah, or means praises to Allah). The process of haircutting is also included in the ceremony.

There have been previous studies related to the practice of certain rituals for baby(s). The first is latest artifact of the Indian's Journal (1888) which has been just published online in 2013, of the birth ceremonies of the Prabhu community in India. Then there are also studies of new-born baby naming practices in the African tribes (Mahwasane \& Tshifaro, 2019) and a narrative ethnography of a baby loss remembrance walk ritual by Willer et al. (2019). Those three previous studies focus on the practice and ritual of a community while this current study focuses on comparing how two different cultures celebrate the newcomers in their family.

\section{Research Method}

This study is a qualitative study comparing two practices of the baby birth welcoming ceremony of Saluan and Korea. In this type of research, researchers act as people who collect information directly. In its application, the method of direct observation is the method recommended in the research process. Where the subject or object of research is visited directly by the researcher and observed its activities in natural situations or conditions (Mauludi, 2018). The author collects some data to support this writing through self-report (from observation), interview, and documentation, and text study. The text study specifically means the literature study that requires empirical significance tests in the field (Muhadjir, 2000).

The process of data collection was from November 2019 to January 2020. Selfreport is derived from the researcher's observation of the practice of baby ceremony in the Saluan tribe, located in the district of Nambo, Banggai Regency. The information about the baby ceremony in Korea was obtained from literature purposively retrieved from internet sources. Face to face interview with a Korean researcher and lecturer, Mrs. Jeon, in an International Conference at the Site Skills Training, Clark Freeport Zone, Philippines is important to support the current information.

\section{Finding and Discussion}

The Concept of New Baby Welcoming Ceremony in Saluan Culture

Generally, the tradition of welcoming a new baby in Saluan culture is often called monsaluk. However, in a narrow scope and specific term, Monsaluk is the process of cutting the child's hairs, like the usual hair-cutting process in Aqiqah. However, monsaluk 
has differences in some ways. For a Saluan baby girl, she will have monsaluk and aqiqah at the same time. Meanwhile, a baby boy will only have monsaluk ceremony and they will have their aqiqah at the age of seven or above. Usually, not before a boy or a girl baby is going to have his/her monsaluk ceremony that they will be given any name. Although it is up to the time and financial consideration of the family of the new baby born, the ceremony was normally held within a week after the baby born

a. Stage

There are three main stages involved in monsaluk, namely momposoop, monsunat, monsaluk, and mompopeja'. The whole process will be taken in one and a half days. Within the whole processes, the family will need an umbrella, a plate of raw yellowed rice, traditional cloth like sarung and peci, white cloth, dozens of green flowers and plants, mirror, a vase of flower, a large traditional powder, equipment of traditional nail art, equipment of baby's future prediction, large trays, and coins (money to be given in the highlight of the ceremony).

\section{1) Momposop}

Momposoop literary has meaning: "making someone get in". In the ritual of momposoop, a baby is held by someone, in front of the bed canopy. An older will push slowly the head of the one who holds the baby three times and after that, the baby in the hold will have to enter the bed canopy. In the past, Saluanesse house should have at least one room where bed with its bed canopy inside. Nowadays, people may use long cloth or curtain to replace the bed canopy if they don't have it at their homes.

However, the baby should have initially followed the bathing and "mombada" and "mompopo"l (traditional make-up and nail art). The baby bathing is often completed in an afternoon, about 15 hours before the process of "monsunat" or 18 hours before "monsaluk", led by a tribe leader (woman for baby girl and man for baby boy). The process is simply drawn like:

\section{2) Monsunat}

Monsunat or circumcision is a single process when some part of the vital organ of a child will be separated from its place. Usually, for girls in Saluan culture, they will have this process along with the "monsaluk" when they were still babies. However, for boys, they will have this after they are five or seven years old. A long time ago, this process will be led by a shaman. At present, many families would rather call a doctor.

\section{3) Monsaluk}

Monsaluk is the ritual where the baby's hairs must be cut. Not all of them will make the baby bald, only some of them, as the symbol of removing bad luck from him/her. This is basically like aqiqah. The leader of the tribe, now should be a man, leads this process. $\mathrm{He}$ recites gratitude to God and also greetings to the Prophet of Muhammad. Once he begins the recitation, the other women and men who gather in the same room should follow him. In the highlight of the recitation, they should stand and begin the process of haircut. After that, they will sit again to finish the session.

\section{Baby's Future Prediction}

There is one step that is also crucial in the event: baby's future prediction. The author seems so hard to find the exact name of this step so she finally uses the term. The family will provide some tools representing any kind of talent. As when the author's cousin followed the same ceremony about seventeen years ago, there were pen, mirror, some cooking game stuff, and coins provided in a large tray. Her cousin chose the cooking game stuff. At present, the author's cousin has become very good at cooking; her skill even much better than the author who is eight years older than her. 


\section{4) Mompopeja'}

After the process of haircut and baby's future prediction, the baby will be taken outside, mostly on the terrace of the house to follow the next session. That is mompopeja'. In Saluan language, mompopeja' means to make the baby's feet touch the ground. The baby's barefoot is the welcoming sign for his/her to the outside world. During this process, some women and men will rise again the gratitude to God within Arabic lyrics but it sounds more Saluanesse called Allaho (from the word Allahu).

While following this step, baby (s) will be held by older women, generally not behold by her or his mother. It might be his/her aunt or grandmother. Besides, a family member will share a dozen candies and money to the guests who have been waiting for this session. People who are the guests and those who are just incidentally passing the house of the family who held the event will eventually gather to wait for the money and candies thrown. This is the most excited and funniest moment of the event.

\section{b. Philosophical Value}

To get more understanding of the philosophical values behind each of the procession in the event, they will be presented in the following table:

Table 1. The Philosophical Value of Saluanesse New Baby Welcoming Ceremony

\begin{tabular}{|c|c|c|}
\hline Philosophical Value & Do's & Taboos \\
\hline 1. Momposoop & & \\
\hline $\begin{array}{l}\text { Baby should be prepared for } \\
\text { the event he/she will follow. } \\
\text { At the same time, the baby } \\
\text { should be protected from the } \\
\text { outside world before he/she }\end{array}$ & $\begin{array}{l}\text { Baby should have a } \\
\text { bathing } \\
\text { traditional maksion, } \\
\text { session, and nail-art } \\
\text { session. }\end{array}$ & $\begin{array}{l}\text { The baby must not be taken } \\
\text { outside of the house (even } \\
\text { in the terrace) after he/she } \\
\text { has the traditional make-up } \\
\text { and nail-art. }\end{array}$ \\
\hline
\end{tabular}
ceremony.

\section{Monsunat}

To banish the bad luck and bad things within the baby's body.

\section{Monsaluk}

To avoid bad things and luck approaches the baby 4. Baby's Future Prediction To see the baby's hidden talent that perhaps will help her to be a successful person in the future.

\section{Moтpopeja'}

To introduce the baby to the outside world. The baby is expected to grow as a strong person, to stand on his/her feet; to be independent.

6. Gift

Baby should have the circumcision process protected, not all people could see him/her, only limited people.
Baby will have to choose the things by her/his self.

A baby girl should be under the care of a woman, and a baby boy should be under the care of a man. By breaking this rule, a family will have a bad fortune in the future.
Parents or other people must not help his/her to see how his/her pure soul reflects his/her future. 


\begin{tabular}{lll}
\hline \multicolumn{1}{c}{ Philosophical Value } & \multicolumn{1}{c}{ Do's } & \multicolumn{1}{c}{ Taboos } \\
\hline $\begin{array}{l}\text { To congratulate the family } \\
\text { who welcomes the new }\end{array}$ & $\begin{array}{l}\text { The gift is generally } \\
\text { money put inside the } \\
\text { white envelope. }\end{array}$ & $\begin{array}{l}\text { Guests who come without } \\
\text { any gift is considered to be } \\
\text { stingy. }\end{array}$ \\
$\begin{array}{l}\text { 7. Candy and Coins Shower } \\
\text { Sharing happiness with other } \\
\text { people }\end{array}$ & $\begin{array}{l}\text { The candy and coins Coins (money) and candies } \\
\text { must be shared along are not allowed to share } \\
\text { with the "mompopeja" before the ritual } \\
\text { ritual. This is to sign "monsunat" } \\
\text { that the whole process "monsaluk", only during } \\
\text { is going to be "mompopeja". Saluannesse } \\
\text { completed }\end{array}$ \\
& $\begin{array}{l}\text { can't remove this part } \\
\text { otherwise, based on the } \\
\text { beliefs, they will have a bad } \\
\text { fortune for being stingy. }\end{array}$ \\
\end{tabular}

\section{The Concept of the New Baby Welcoming Ceremony in Korean Culture}

Long has been the Korean tradition to celebrate a baby's first birthday in the form of a grand ceremony, called Doljanchi (1st Birthday Party). The highlight of the ceremony is called the Doljabi.

Mrs. Jeon (an interviewee) state:

"Dol is the first birthday of Koreans: boy and girl. They have a huge party on their first birthday. So you invite all your relatives, friends, etc."

The party is held a year after the baby was born. It is when the baby turns 12 months. However, it does not refer to his/her age in Korean's calculation. In Korea, children's age is counted since they were still in the womb. So, they likely have two age calculations both in Korean and in general. The Korean age is a year older.

a. Stages

1) Opening

There is the main stage in front of the hall where the event is held. That stage is the place of the core family. There is also the master of ceremony (MC) that will guide the event. The MC will give the floor to the family leader (father) to give an opening speech, thanking the guests who have made their time to attend the event.

After that, the family will give a special presentation to the guests. It can be a documentary video of the baby from the first time he was born until the moments of preparing his first birthday celebration.

When the video playing is finished, the guests give applause and prepares for the next and the highlight of the event. The baby will be taken into the restroom. He will be transformed from casual/formal cloth in a tuxedo to be traditional and charming Korean hanbok.

\section{2) The Highlight of the Ceremony}

In the highlight of the ceremony, the doljabi, there is a person as the "conductor" of the Dol show/ceremony (Jeong, 2019). MC will call some people to prepare the doljabi table. The doljabi table will be the place of some traditional cakes and foods, fruits, and the doljabi sets (tools that will be chosen by the baby). The doljabi sets represent professions or talents, like a soccer ball (football player), tennis ball (tennis player), ancient coins (to make the baby rich in the future), archery (be a good archery athlete), baseball (baseball player), shuttlecock (badminton player), etc. Other parents may provide various items like can be seen in the following table. 
Table 2. Some Items Used in Doljabi

\begin{tabular}{|c|c|c|}
\hline Item & Symbolize & Meaning \\
\hline Gavel & Judge/Lawyer & $\begin{array}{l}\text { Looks like the child is already working } \\
\text { towards being the respected judge in } \\
\text { town. }\end{array}$ \\
\hline Stethoscope & Doctor & $\begin{array}{l}\text { The child is destined to heal the people } \\
\text { around the world. }\end{array}$ \\
\hline $\begin{array}{l}\text { Piggy Bank, } \\
\text { Money }\end{array}$ & Entrepreneur & $\begin{array}{l}\text { The child will figure out a way to become } \\
\text { a successful business person. } \\
\text { Entrepreneurs are always thinking outside } \\
\text { the box. }\end{array}$ \\
\hline $\begin{array}{l}\text { Graduation } \\
\text { Cap, Books }\end{array}$ & Scholar & $\begin{array}{l}\text { The outlook for the child shows that } \\
\text { he/she will be a smart one. There are } \\
\text { countless ways he/she can use his/her } \\
\text { scholarly brain to achieve greatness. }\end{array}$ \\
\hline Microphone & $\begin{array}{l}\text { Journalist/ Performing } \\
\text { Artist/Movie } \\
\text { Star/Celebrity }\end{array}$ & $\begin{array}{l}\text { The child is going to have a very good } \\
\text { singing voice. }\end{array}$ \\
\hline $\begin{array}{l}\text { Test Tubes, } \\
\text { Other Science } \\
\text { Objects }\end{array}$ & Scientist/Inventor & $\begin{array}{l}\text { The child may have the gift to create } \\
\text { inventions that will shape the world for } \\
\text { years to come. }\end{array}$ \\
\hline
\end{tabular}

(Doljabi, 2016)

After the table is ready, the baby will be put on the table, under the guidance of his parents, to choose anything he wants. Like we can see in the following pictures, there are some doljabi sets, but the baby boy has finally chosen the soccer ball. After the completion of the doljabi, the doljanchi will be closed in a moment. The family thanks to the guest for their comings and then the guests will leave the place orderly.

b. Philosophical Value

Based on the article from Doljabi (2016), Doljabi is a ceremony that blesses the child with a prosperous future and a healthy life. It is a tradition where 6-8 various items are placed on a traditional Korean blanket and then the child is placed in front of the items. Once the child is placed in front of the objects he, or she, is encouraged to grab one or two of the items. The item(s) that the child picks represents the future for the child, such as a lifestyle or career.

To appreciate and honour the family who celebrates the first birthday of their son or daughter, guests should bring a gift to the event. Those who come without presents will be considered impolite and do not honour the family; in fact, there will be no guest coming with an empty hand. 


\section{Conclusion}

As the conclusion of this paper, the author underlines the difference between the new baby welcoming ceremonies in the two cultures in terms of time and the number of events involved.

The new baby welcoming celebration in Saluan culture is closer to the time of the baby born rather than the Korean culture which takes about a year after the baby was born. The new baby welcoming celebration in Saluan culture has more steps to follow than the Korean's, and so it is conducted a little bit longer. Both Saluan culture and Korean culture has a baby's future prediction in the ceremony and include gifts from the guests as an essential element that should not be forgotten.

There is also an interesting fact of how languages of the two cultures used in the highlight events that had not been explored further in this paper. Thus, it can be a good topic to deal with in the future studies.

\section{References}

Doljabi. (2016). What is Doljabi? Retrieved September 20, 2012, from Doljabi, Korean Traditional 1st Birthday Party Planning Source website: https://www.doljabi.com/what-is-doljabi/

Journal, T. F. (1888). Birth Ceremonies of the Prabhus. The Folk-Lore Journal, 6(1), 7577. Available online since 2013. Retrieved March 28, 2020, from https://doi.org/10.1080/17442524.1888.10602877

Mahwasane, M. M., \& Tshifaro, T. J. (2019). New-born baby naming practices of the Vhavenda: A sociolinguistic analysis perspective. South African Journal of African Languages, 39(2), 175-184. https://doi.org/10.1080/02572117.2019.1618016

Mangundap, P., Waani, J. O., Tungka, A., Doda, L. S., \& Doda, B. (2017). Saluan Loinang Baloa Doda Di Kabupaten Banggai. Jurnal Fraktal, 2(2), 11-21.

Mauludi, E. (2018). Penelitian Deskriptif Komparatif dan Asosiatif. Retrieved March 28, 2020, from Teknologi Informasi Komunikasi - Portal Ilmu Komputer, Sistem Informasi, Metodologi Penelitian, Matematika, Algoritma, dan Pemrograman Komputer. website: https://www.elfanmauludi.tech/2018/09/penelitian-deskriptifkomparatif-dan.html

Muhadjir, N. (2000). Metode Penelitian Kualitatif (4th ed.). Yogyakarta: Rake Sarasin.

ParentMap. (2005). Welcoming Baby Birth Rituals Provide Children with Sense of Community, Culture. Retrieved from ParentMap website: https://www.parentmap.com/article/welcoming-baby-birth-rituals-provide-childrenwith-sense-of-community-culture

Willer, E. K., Krebs, E., Castaneda, N., Hoyt, K. D., Droser, V. A., Johnson, J. A., \& Hunniecutt, J. (2019). Our babies['] count[er story]: A narrative ethnography of a baby loss remembrance walk ritual. Communication Monographs, O(0), 1-21. https://doi.org/10.1080/03637751.2019.1666289 